\title{
Corequisite Courses for Developmental Students at a Large Research University
}

\author{
Hillary Procknow, University of Texas at Austin \\ Leta Deithoff, University of Texas at Austin \\ Van Herd, University of Texas at Austin
}

\section{ABSTRACT}

This article details the efforts that the Texas Success Initiative (TSI) office at a large research university made toward piloting, refining, and scaling corequisite courses for students who require developmental education. House Bill 2223, passed by the Texas Legislature in June of 2017, requires public institutions to increase the percentage of developmental students enrolled in corequisite courses. In response, student outcome data, curricular examples, and suggestions for structuring corequisites are presented.

W hen the 85th session of the Texas Legislature completed its work in June 2017, House Bill 2223 (HB 2223) was passed, requiring that beginning in Fall 2018 , a minimum of $25 \%$ of students needing development in each area (reading/writing and math) were required to be enrolled in corequisite courses. Each subsequent year will require a $25 \%$ increase of enrollment in corequisites, reaching the maximum requirement of $75 \%$ enrollment in corequisites beginning in Fall 2020.

\section{Student Population}

\section{Program Overview}

For the past 4 years, the Texas Success Initiative (TSI) program at the University of Texas (UT) at Austin has been piloting and scaling corequisite courses for students who are not college-ready in reading/writing and math. People are often surprised to learn that UT Austin has a developmental education program. While the TSI student population is small, an important goal of the university is to ensure all entering students are adequately prepared to succeed in the demands of their college course work.

The university evaluates students for TSI status according to state statute and follows the same guidelines for assessing and identifying TSI students as do all public institutions in the state of Texas. The majority of students needing developmental education are those admitted to the university under Texas's 10\% rule, which grants automatic admission to any Texas Institution of Higher Education (IHE) for all Texas high school students who finish in the top 10\% of their graduating class. This means that a large portion of our students graduated at the top of their high school classes but frequently attended underserved high schools with fewer academic and extracurricular resources. In fact, 67\% of developmental students entering in the Fall 2016 cohort came from families with incomes less than $\$ 60,000$ compared to the population of UT Austin at large, for which only $27 \%$ come from families with incomes less than $\$ 60,000$. As documented in several places, students who come from lower-income families are more likely to struggle academically (Berman et al, 2018; Berliner 2006; Jensen, 2013).

More than $90 \%$ of students in developmental courses at the university are students of color, which is reflected in the American Psycholgoical Association's observation that race, ethnicity, and socio-economic status are strongly related (2018). Due to systemic racism and policies that that prevent people of color from achieving greater economic success (Solomon \& Weller, 2018), students of color are more likely to live in poverty and therefore experience lower academic achievement. For example, 50\% of students needing developmental courses are Hispanic, compared to an overall Hispanic population of only $25 \%$ at the university. Similarly, $30 \%$ of students needing developmental courses are Black despite comprising only $5 \%$ of the university population. In addition, the majority of developmental students at UT are first-generation college students, a population that research indicates "experience difficulties prior to and during their college experience that make them vulnerable to lower academic performance" (Ramoz-Sánchez \& Nichols, 2007, p. 6). Because of these factors, the TSI program at UT recognizes the need to ensure students are connected to programs across campus that will support them and to provide engaging and personally relevant material.

Corequisite Structure and Scheduling

In Fall 2014, the TSI office piloted one corequisite course for students needing development in reading/ writing and one corequisite course for students needing development in math. Current literature-in particular, 
reports based on the Accelerated Learning Program out of the Community College of Baltimore County (2018)-has focused on corequisite models in which the same instructor teaches both the credit-bearing course as well as the developmental corequisite course. However, some documented drawbacks include potential negative outcomes for the college-ready students in credit courses (Goudas, 2017). Furthermore, there are a number of administrative and bureaucratic challenges to implementing that format at UT Austin since separate departments house the developmental, non-credit bearing courses (undergraduate studies) and the credit-bearing corequisite courses (math, statistics \& data science, and rhetoric). Thus, differential departmental hiring practices and difficulties sharing faculty between departments dictate that students attend corequisite courses taught by faculty in corresponding departments, and attend developmental sections taught by TSI faculty.

The developmental corequisite course for reading and writing has a maximum enrollment of 15 students per section and is paired with the university's single-semester introductory composition course. The introductory composition courses have an enrollment limit of 25 students and share a common syllabus. Because our program does not want to fill more than half of a single introductory composition section with students needing developmental courses, and because the composition syllabus is shared across sections, students enrolled in developmental courses are able to enroll in any section that does not conflict with the developmental corequisite. To ensure the availability of enough seats in composition for developmental students, the TSI office works with the Rhetoric department to reserve a small number of seats across three sections. However, students are encouraged to register for open sections on their own if they are able.

The developmental corequisite course meets at a fixed time and location for 1.5 hours each week throughout the regular long semester. This corequisite is offered as a zero-credit hour course on a pass/fail basis and appears on students' transcripts. Table 1 demonstrates how the composition and math courses as well as the developmental sections are scheduled.

Math corequisite courses are structured similar to the composition corequisite courses and are paired with Math for Liberal Arts and two different introductory statistics courses. The developmental corequisite courses for math are also limited to 15 students per section. The primary difference between the composition course and the math courses is the number of students enrolled in the credit course. While the composition courses are small in size, the math courses range in enrollment between 100200 students. For this reason, we are typically able to place all 15 students in the developmental math corequisite course in the same large section of Math for Liberal Arts or introductory statistics. The TSI office works with the Department of Math and the Department of Statistics and Data Science to reserve seats in one of these sections, allowing the instructor of a developmental corequisite course to communicate with a single math instructor when necessary and to focus on concepts and assignments on which all students in that section are working.
Table 1

Sample Scheduling for Credit-bearing and Developmental Corequisite Courses

\begin{tabular}{lll}
\hline $\begin{array}{l}\text { Develop- } \\
\text { mental area }\end{array}$ & Credit-bearing course & $\begin{array}{l}\text { Paired, zero-hour } \\
\text { developmental core- } \\
\text { quisite }\end{array}$ \\
\hline $\begin{array}{l}\text { Reading } \\
\text { and Writing }\end{array}$ & $\begin{array}{l}\text { Introductory Composition: } \\
\text { Any section that does not conflict } \\
\text { with the corequisite } \\
\text { Total students in credit course: }\end{array}$ & $\begin{array}{l}\text { Thursdays; 11- } \\
12: 30 p m\end{array}$ \\
& 25 & \\
\hline Math & Math for Liberal Arts: Monday, & $\begin{array}{l}\text { Tuesdays; 11- } \\
\text { Wednesday, Friday; 9:00- }\end{array}$ \\
& $\begin{array}{l}\text { 10:00am } \\
\text { Total students in credit course: }\end{array}$ \\
& 125 & \\
\hline Math & Introductory Statistics: Monday & $\begin{array}{l}\text { Tuesdays; 8:00- } \\
\text { and Wednesday; 3:00-4:30pm }\end{array}$ \\
& Total students in credit course: & \\
& 200 & \\
\hline
\end{tabular}

While the desired student outcomes for developmental corequisite courses must match the desired student outcomes for the credit course, the goal of our corequisites is never to double, or even substantially increase, the workload of the students. The goal is to provide the students with the space to ask questions, practice, work on concepts they may have missed in high school, and think critically about the area they are developing. Therefore, students in corequisite courses will have homework though not extensive. Assignments supplement the kind of work and ideas students will produce in their paired credit course and, in some cases, in their future academic endeavors. Curricular decisions and activities are detailed in the following sections.

\section{Student Placement Practices}

Each student goes through a holistic review as required by the TSI statute (Title 19, Rule $\S 4.57$ of the Texas Administrative Code). In the first years of offering corequisite courses, the TSI program considered enrolling students who scored between 347 and 349 on the TSI Assessment (TSIA) in the math corequisite course. In an effort to increase the percentage of students in corequisite math courses in anticipation of HB 2223 requirements, in the Fall of 2017, TSI staff decreased the minimum score for entry into math corequisites to 345 . In addition to students' scores on the TSIA, the director of the program reviews students' records including the number and level of math courses completed in high school, their grades in those courses, and other academic and personal factors as put forth by the Texas Higher Education Board (THECB), the state agency that oversees IHEs and operationalizes state statutes. When students attend their TSI advising appointment during Summer orientation, the TSI advisor explains to them the benefits of enrolling in the corequisite model. If students insist that they would rather take the semester-long course in the Fall and the credit course in the following semester, staff allows them to do so, but this is a rare occurrence. When students' scores on the TSIA are close to the cut-off score for the corequisite model, TSI advisors work with the student during their advising appointment to determine a student's motivation and level of comfort in the area. If students express that they feel comfortable with math and 
think they will do better in a corequisite model, advisors allow them to enroll. Consequently, students with scores as low as 339 on the math section of the TSIA have succeeded in the corequisite model.

Similar rules apply for the holistic placement practices concerning the reading/writing corequisite course. Because the TSI statute requires that all exit-level developmental reading and writing courses must be integrated, the corequisite course in the English area integrates reading and writing and is paired with the university's introduction to composition course. The majority of students in the corequisite course $(88 \%)$ have passed the writing section of the TSIA. During the initial years of offering the corequisite model, students who earned scores of 348 to 350 in reading were considered for the corequisite course. In Fall 2017, TSI staff lowered the minimum reading score for placement into the corequisite to 346 . As with the math corequisite, TSI advisors determine borderline cases during appointments and place motivated students with strong high school academic records in corequisites. By pairing the corequisite course with a writing intensive course, students have a semester to practice and strengthen their writing skills and also to develop college reading skills across a number of disciplines.

\section{Reading and Writing Corequisite Courses Premise and Structure}

Based on the idea that reading and writing "should be viewed as a single act of literacy" (Quinn, 1995, p. 295) and the focus of every assignment and text (Holschuh \& Paulson, 2013), the reading/writing corequisite (DEV $000 \mathrm{~W}$ ) presents students with texts from the different disciplines they will encounter in college (i.e., history, psychology, biology, sociology, economics) and asks them to mimic the language of that discipline in various written responses (e.g., journal entries, short answer responses, critical analyses, essays, etc.).

Early in the semester, the instructor provides a variety of low-stakes activities (Elbow, 1997), such as daily journal prompts that focus on practice and idea generation. Such low-stakes activities are paired with student-centered texts (i.e., essays on current topics, engaging short stories, such as Evan Hunter's On the Sidewalk Bleeding (1957), and familiar disciplines such as rhetoric or literature) to build proficiency, self-efficacy, and motivation through success on small tasks. As students engage with the varied texts, they learn to read "with two minds" (Hjortshoj, 2009, p. 37), that is, to analyze what authors say and how they say it. Students then apply this dual focus to their own writing, creating solid content that mimics the demands of a specific discipline and utilizes effective writing practices to produce well-developed, well-supported responses. Additionally, students learn to study smarter, not harder, so tasks incorporate metacognition to assess what future tasks will ask of them and how to approach these tasks (El-Hindi, 2003).

Readings and subsequent essays become more challenging as the semester proceeds so that students can apply new reading and writing strategies to the disciplines they will experience beyond the developmental classroom. Higher-stakes writing measures (Elbow, 1997) serve as the basis of assessment while preparing students for the demands of their paired introductory composition course.

\section{Detailed Examples}

To illustrate the kind of work students produce in the developmental corequisite course, the examples below present two assignments: an early semester, in-class activity that models the necessary depth, support, and analysis required in a short answer response; and an end-of-semester, discipline-specific (science) writing assessment.

The in-class activity asks students to examine Norman Rockwell's 1943 images representing his interpretation of America's Four Freedoms referenced in Smithsonian (Tucker, 2018). The four photographs attempted to muster popular interest towards America's involvement in World War II, so the students analyze how Rockwell constructed his images and subsequently evaluate whether he was successful in his purpose. Then students compare these images to the four newly created images compiled by Abigail Tucker for Smithsonian in an attempt to re-envision the Four Freedoms for 2018. Tucker's online article presents and discusses many of the rhetorical issues associated with these images, making it a good resource for the instructor to frame the activity. Students evaluate the differences and answer questions such as:

- How have ideals changed since Rockwell's time?

- What changes did the artists have to make in order to reflect these new ideals? (Use description from the images as evidence.)

- Do the new images accurately reflect the American beliefs and values of 2018 ? Why or why not?

For the final assignment, students must first read Harry Harlow's The Nature of Love (1958), an early premise for attachment theory based on researchers' observations that "contact comfort" was such "an important basic affectional or love variable" for orphaned rhesus monkeys that it seemed "to overshadow so completely the variable of nursing," leaving Harlow to conclude: "Love is an emotion that does not need to be bottle- or spoon-fed" (p. 677). Students dissect the scientific text and construct arguments based on their interpretations. They then conduct a debate on the ethics of animal experimentation in research. Finally, they write a paper supported by the original text and one additional piece of research, answering the question: "Were Harry Harlow's monkey experiments ethical?" in a manner suitable for the audience of a science-based journal.

Both of these examples show a progression of tasks in terms of their proximity to students' interests and familiarity as well as in degrees of increasing length and difficulty. As Table 2 conveys, by the end of the semester, $88 \%$ of students are ready for their credit courses, regardless of the discipline. 
Table 2

Score Ranges for Students Placed in Reading/Writing Corequisite Course and Student Outcome Data for 2016-2017 and 2017-2018

\begin{tabular}{|c|c|c|c|c|c|c|}
\hline $\begin{array}{l}\text { Corequi- } \\
\text { site area }\end{array}$ & $\begin{array}{l}\text { Paired } \\
\text { course }\end{array}$ & $\begin{array}{l}\text { TSIA score } \\
\text { range }\end{array}$ & $\begin{array}{l}\text { Total } \\
\text { num- } \\
\text { ber of } \\
\text { stu- } \\
\text { dents }\end{array}$ & $\begin{array}{l}\text { Average } \\
\text { grade } \\
\text { earned } \\
\text { in credit } \\
\text { course }\end{array}$ & $\begin{array}{l}\text { B- or } \\
\text { high- } \\
\text { er }\end{array}$ & $\begin{array}{l}\text { C- or } \\
\text { high- } \\
\text { er }\end{array}$ \\
\hline $\begin{array}{l}\text { Reading/ } \\
\text { Writing }\end{array}$ & $\begin{array}{l}\text { Introducto- } \\
\text { ry composi- } \\
\text { tion }\end{array}$ & $\begin{array}{l}\text { Reading: } \\
\text { 340-360 } \\
\text { Writing: } \\
\text { 346-382 } \\
\text { Essay: 3-7 }\end{array}$ & $\begin{array}{l}26 \\
(100 \%)\end{array}$ & 2.82 & $\begin{array}{l}17 \\
(65 \%)\end{array}$ & $\begin{array}{l}23 \\
(88 \%)\end{array}$ \\
\hline
\end{tabular}

\section{Assessment}

To measure student progress, assignments in the developmental corequisite course should demonstrate a greater command of the writing stages and an awareness of audience influence on the resulting text. Specifically, essays should avoid what Hjortshoj (2009) identified as common perceived weaknesses in student writing: "unclear theses and arguments, insufficient thought about the topic, poor organization and logical development, and careless proofreading" (p. 58). This focus is particularly important since the students are co-enrolled in the introductory composition course, which asks them to navigate the idea of good persuasive writing-and is credit bearing. Thus, the developmental corequisite course provides ample opportunity for discussion about and practice of effective writing techniques while varying between lowstakes daily assignments and four higher-stakes writing measures as student proficiency increases.

Table 3 illustrates the breakdown of the assignments based on a 100-point scale. The first two assignments are worth fewer points as students improve grammatically and structurally. Journal entries are daily, free-writing assignments in response to a text, quote, or suggested topic. They are graded during three journal checks for content and idea generation depth rather than grammar or mechanics to promote better quality and lower stress responses.

Table 3:

Assignment List for the Reading/Writing Corequisite Course

\begin{tabular}{ll}
\hline Assignment & Point Value (100 points total) \\
\hline $\begin{array}{l}\text { 1: Reading Response to an } \\
\text { excerpt from The Cellist } \\
\text { of Sarajevo by Steven } \\
\quad \text { Galloway }\end{array}$ & 15 \\
$\begin{array}{l}\text { 2: Rewrite Activity-Revision of } \\
\quad \text { a sample musical rhetorical } \\
\text { analysis }\end{array}$ \\
$\begin{array}{l}\text { 3: Cross-discipline Comparative } \\
\quad \text { Short Answer Analysis }\end{array}$ \\
$\begin{array}{l}\text { 4: Harry Harlow Response: Is } \\
\quad \text { animal research ethical? }\end{array}$
\end{tabular}

\section{Suggestions From Practice}

After 4 years of teaching integrated reading and writing corequisite courses similar to the one presented above, TSI staff and instructors have learned what benefits students through trial and error. The early developmental courses were paired with a common history course because students often struggle with reading primary sources vs. secondary historical sources, using these sources as evidence in essay responses, understanding how to answer and study for essay exams, and, generally, knowing how to be successful in a history class. Student performance throughout the semester demonstrated that, while preparing for and often passing the first history test was challenging despite a student's preparation level, students soon learned how to be successful on subsequent exams in the history course and readily adapted to the demands of the texts, especially later in the semester as readings moved closer to present-day language and concerns. This improvement left less to discuss in the latter part of the reading/writing corequisite. The steep learning curve experienced in freshman history mirrors what students face in other courses once they leave developmental education. Therefore, it seemed more beneficial to expose students to multiple disciplines while helping them develop the skills to adapt to a college environment's changing demands.

Thus, pairing the developmental corequisite course with the university's introductory composition course became the obvious choice. Additionally, students tend to want support throughout the semester in introductory composition as the assignments move from summarizing multiple sources, to critical evaluation, to the final production of a research-based argument on a controversial topic. Therefore, developmental students meet once a week with their developmental corequisite instructor to discuss topics that build general learning strategies, support various reading and writing tasks, and prepare students for the content provided during their composition classes. The instruction in both courses helps students transfer newly-acquired rhetorical knowledge to broader academic requirements.

Experience also reveals both pros and cons for how to grade the developmental corequisite course. Despite rigorous assignments and grading standards, students ultimately receive a pass/fail score in the developmental corequisite course. Consequently, students are not penalized for taking a non-credit-bearing course in addition to their full semester demands. Emphasis shifts to their credit-bearing courses, and the corequisite becomes support for those courses rather than a distraction.

One drawback to UT's current corequisite model rests in the scheduling challenges it presents. Since the developmental corequisite course meets only once a week, addressing issues for students with specific or limited time demands can be problematic. This drawback will be addressed further in the final section of the paper. The pass/fail emphasis presents another obstacle in that 
it can negatively impact performance motivation as some students strive to do just good enough on their tasks. In general, though, the current model provides students with enough practical assessment opportunities that they will learn and progress even if they are just completing the minimum requirement.

Overall, student results suggested that this model is instrumental in helping students succeed in their future classes as evidenced by the success rates for the students enrolled in this corequisite in the 2016-2017 and 20172018 academic years presented in Table 2.

\section{Math Corequisites}

The vast majority of students needing math development at the university are required to complete only one math course for their degree plans. This requirement is satisfied most often with Math for Liberal Arts and one of the two different versions of introductory statistics offered at the university. As noted above, while students in the reading/writing corequisite can enroll in any section of composition, due to smaller class sizes and a common syllabus, students in math corequisites are enrolled in a single section of Math for Liberal Arts or statistics. The large class sizes of math courses allow for TSI advisors to place up to 15 students in a single section without disrupting the normal conduct of class, which also ensures that each student in the developmental corequisite is doing the same work in the credit class at the same time.

\section{Math for Liberal Arts Overview}

As is the case in the reading/writing corequisite, the corequisite course paired with Math for Liberal Arts aims to not only support students in their credit course but also to introduce students to concepts and ideas they will be encountering in future course work. The University of Texas at Austin has a long history of leading mathematics pedagogy and methodology from the time of the storied Robert Lee Moore and his inquiry-based approach to mathematics education and the production of knowledge (Parker, 2005). Inquiry-based instruction has borne great pedagogical fruit, expanding far beyond its original home to become an international movement, and inquiry-based education continues to occupy a prominent position in the corequisite mathematics curriculum at the university. Transcending this practice is the recognition of the mathematical process known variously as complectification, popularly subsumed under the rubric of complexity (Rescher, 1998).

To this end, the instructor for the corequisite math course has endeavored to evolve an exposure or complexity model of mathematics education, which fits the corequisite desiderate handsomely. For example, corequisite education transcends standard tutoring and putative remediation and is meant to be an active looking ahead-that is, equipping and exposing students in a low-stakes setting to the upcoming conceptual challenges they will be facing, for example, in the next lecture or next module. By the very act of exposure to the concept in the corequisite environment, students are now ready to face the conceptual challenge when it faces them in a non-scaffolded environment.

This exposure in the developmental corequisite course is all the more necessary given that in the current arrangement, the instructor for the developmental corequisite course does not teach the Math for Liberal Arts course in which the students in developmental education are enrolled. Nevertheless, the instructor of developmental education has a symbiotic teaching relationship with the instructor(s) of the credit-bearing course, who have proven to be supportive of the corequisite work. Vital to this partnership has been access to the online learning management system and student records as well as to lesson plans and homework so that the corequisite instructor may align dynamically the module requirements with the credit course.

\section{Course Structure}

Math for Liberal Arts is typically taught with Burger and Starbird's canonical textbook, The Heart of Mathematics (2009). Following is a description of daily activities and assignments from the developmental corequisite in anticipation of the credit-bearing course covering an extract from Chapter 2 of the text, "Number Contemplation" (which chapter serves as an ideological anchor for the course). In advance of the day's activities, the corequisite instructor has reviewed the syllabus for Math for Liberal Arts and is aware of upcoming assignments and exams. Typically, the corequisite course instructor is working ahead according to the exposure model of mathematics pedagogy discussed above. This is very important. While the corequisite instructor can (and should) function in the role of a tutor or course supplement, that is not the main function of the corequisite instructor. Rather, their role is to teach ahead of the main section such that when students are met in plenary session, topics are not new but rather familiar due to having been discussed previously.

\section{Detailed Example}

For this activity, the students enrolled in the developmental corequisite course meet at the Harry Ransom Center (HRC), a renowned archive housed at the University of Texas at Austin to examine the History of Mathematics holdings. This meeting place is not unusual as the class has several field/applications experiences throughout the semester. Context-rich experiences such as these 
are one of the luxuries of a research institution for such a course as this. Readers are encouraged to contact the authors for more specific implementation instructions for these enrichment exercises. The works to be studied were selected by the instructor in consultation with the curator and librarians of the HRC. For example, one of the concepts used by the Math for Liberal Arts instructor and mentioned orthogonally in the Heart of Mathematics text were magic squares. Hence, several works containing magic squares were pulled for the students to study. Chief among these are John Dee's 16th-century magic squares and magical mathematical tables (known from the posthumously-published $A$ true and faithful relation (1659)), Johannes Kepler's Harmonices mundi (1617), and Luca Pacioli's 1494 Geometria that the University of Texas owns in a later condensation, known as De Divina proportione (1509), with illustrations and figures provided by Pacioli's former mathematics student, Leonardo de Vinci. Also studied were the diverse manners in which mathematical equations are presented and the ways in which these have changed over the intervening centuries. Thus, students obtain a clear sense of historical development and the influence that history has exerted upon mathematical concepts. In this particular lesson, the instructor covered Leonardo of Pisa, culminating in a review of the Fibonacci series that was begun in the previous week. This lesson culminated in an assessment that required the return to the HRC to select one of the books that had been discussed and to write a brief bibliographic description of it according to a simplified template. Students were also required to select a simple mathematical equation or symbol from the books they selected and to write a brief paragraph about it in the report. For occasions when students are in the classroom and not out experiencing the resources available to them on the campus, a typical day's classroom schedule is presented in Table 4.

Table 4

Sample Daily Class Schedule Template for the Developmental Corequisite Course Supporting Math for Liberal Arts

1. 10 minutes Roll Call using ice breaker review of mathematical concept covered in last period.

2. 25 minutes Exercise with mathematical manipulatives (or games) of upcoming concepts in M 302.

3. 15 minutes Textbook review in which instructor highlights important sections pertaining to concepts to be covered in M 302 in the next 2-3 sessions; that is, before DEV $000 \mathrm{M}$ meets again. It is vital that the text is emphasized because success in M 302 is commensurate with the amount of student exposure to the anchoring text.

\begin{tabular}{ll}
\hline 4. 20 minutes & Homework review of current homework \\
\hline 5. 10 minutes & $\begin{array}{l}\text { Homework orientation to concepts not yet as- } \\
\text { signed in } \mathrm{M} 302 .\end{array}$ \\
\hline 6. 10 minutes & $\begin{array}{l}\text { Exit ticket [varies] that can be to solve a quick, } \\
\text { simple equation already covered in the day's class. } \\
\text { It is important that the session end even more } \\
\text { strongly than it began, leaving students with a defi- } \\
\text { nite sense of mathematical accomplishment. }\end{array}$
\end{tabular}

\section{Assessment}

Finally, examinations are not given in the developmental corequisite, but graded exercises, usually built upon the homework, are assigned. Moreover, the instructors coordinate closely such that when an examination in the credit course approaches, the corequisite instructor holds an extended review session either in addition to or in lieu of the corequisite class meeting that week. Similarly, an extended mathematics festival is held during finals week, usually on the day of the final for the credit course such that students may drop by to review for the final in a structured come-and-go session, submit any final projects, or catch-up on assignments. This session is also designed to give the students a rich mathematical context, but, above all, a strong psychological boost immediately before they enter upon the final examination.

\section{Introductory Statistics}

Having completed its third academic year, the statistics corequisite was developed initially to support a more algebraically intensive introductory statistics course. In the Fall of 2017, the Statistics and Data Science department created a second introductory statistics course that required less algebraic calculation and focused more on statistics concepts. During that semester, the students in both statistics courses were enrolled in the same section of the developmental corequisite, but as will be discussed, in the future, students in these two courses will be enrolled in separate corequisites. The aim with the statistics corequisite course matches the aim of the corequisite course paired with Math for Liberal Arts. That is, the corequisite course not only supports the students in the work with which they are currently engaged in the credit course, but it also introduces students to the concepts that will be taught in near-term so that they will be familiar with them before they are formally presented in the credit course.

\section{Suggestions From Practice}

Both statistics courses have proven difficult for incoming students who have not demonstrated college-readiness in math. Feedback from the instructor for these credit courses resulted in the implementation of a requirement in the developmental corequisite courses that students must meet with one of the learning specialists in the campus's learning center. Each student in the developmental corequisite course will be required to make a one-on-one appointment with a learning specialist before the first exam in statistics to discuss study strategies and cover metacognitive self-assessment skills. Then, students will be required to see the same learning specialist after the first exam to reflect on areas that the student will need to continue to work on and how they can employ or refine study strategies to help improve their performance on the next exam. Table 5 presents the success rates for students in the developmental corequisite and each of the three credit math courses. 
Table 5

TSI Score Ranges and Average Grades Earned in Credit Corequisite Courses for Academic Years 2016-2017 and 2017-2018

\begin{tabular}{|c|c|c|c|c|c|c|}
\hline $\begin{array}{l}\text { Core- } \\
\text { quisite } \\
\text { Area }\end{array}$ & $\begin{array}{l}\text { Paired } \\
\text { Course }\end{array}$ & $\begin{array}{l}\text { TSIA } \\
\text { score } \\
\text { range }\end{array}$ & $\begin{array}{l}\text { Total } \\
\text { number } \\
\text { of stu- } \\
\text { dents }\end{array}$ & $\begin{array}{l}\text { Average } \\
\text { grade } \\
\text { earned } \\
\text { in credit } \\
\text { course }\end{array}$ & $\begin{array}{l}\text { B- or } \\
\text { high- } \\
\text { er }\end{array}$ & $\begin{array}{l}\text { C- or } \\
\text { high- } \\
\text { er }\end{array}$ \\
\hline Math & $\begin{array}{l}\text { Math for } \\
\text { Liberal Arts }\end{array}$ & $\begin{array}{l}336- \\
349\end{array}$ & $\begin{array}{l}18 \\
(100 \%)\end{array}$ & 3.07 & $\begin{array}{l}14 \\
(77 \%)\end{array}$ & $\begin{array}{l}17 \\
(94 \%)\end{array}$ \\
\hline Math* & $\begin{array}{l}\text { Introductory } \\
\text { statistics } \\
\text { (less } \\
\text { emphasis } \\
\text { on algebraic } \\
\text { calculations) }\end{array}$ & $\begin{array}{l}341- \\
349\end{array}$ & $\begin{array}{l}8 \\
(100 \%)\end{array}$ & 2.29 & $\begin{array}{l}3 \\
(38 \%)\end{array}$ & $\begin{array}{l}7 \\
(88 \%)\end{array}$ \\
\hline Math & $\begin{array}{l}\text { Introductory } \\
\text { statistics } \\
\text { (greater } \\
\text { emphasis } \\
\text { on algebraic } \\
\text { calculations) }\end{array}$ & $\begin{array}{l}345- \\
349\end{array}$ & $\begin{array}{l}16 \\
(100 \%)\end{array}$ & 2.22 & $\begin{array}{l}4 \\
(27 \%)\end{array}$ & $\begin{array}{l}14 \\
(87 \%)\end{array}$ \\
\hline
\end{tabular}

Note: The data for the first listed statistics course are only from Fall 2017, as that is the first semester this particular corequisite was offered.

\section{Discussion of Challenges and Future Plans}

As previously stated, efforts to establish successful corequisite models in both reading/writing and math have met some challenges. The authors hope that discussing them here will be of value to other institutions as they build their corequisites models.

Issues with the corequisite model for the statistics courses have been particularly demanding. The initial math corequisite course was paired with Math for Liberal Arts, but an increasing number of degree programs require a statistics course. TSI staff found that many firstyear students are encountering statistics and statistical thinking for the first time, which is conceptually difficult for them to grasp. For the first time, in the Fall of 2017, developmental students were placed in two different statistics courses while attending the same developmental corequisite course, which meant the instructor for the developmental corequisite course had to divide at least some of the class time between students grappling with different assignments and concepts. Beginning in Fall 2018 , there will be two separate developmental corequisite courses so that the students in each section are enrolled in the same statistics course.

Clearly, the most looming challenge is that of meeting the demands of HB 2223, which requires a continued increase in the percentage of students enrolled in corequisites to meet the $75 \%$ benchmark in Fall 2020 . Increasing the percentage of students in corequisites means placing students with lower TSIA scores into these courses while still ensuring they are academically supported. To accomplish this, beginning in Fall 2018, the university will be offering a 3-hour corequisite model (in comparison to the current 1.5-hour model). This format will add a second day that will function as a laboratory during which students can get supervised help with any of their coursework, and the instructor can address conceptual challenges common to many students.

\section{Two-Day Model Benefits}

In addition to increasing the percentage of students in corequisites, this format will also alleviate a number of other smaller issues. As was referred to above, one of the hurdles for students enrolling in the 1.5 hour per week corequisite (which is a zero-credit hour course) is that it takes the time slot of what could be another 3-hour course. To clarify, if the corequisite meets on Tuesdays from 11:00-12:30, a student cannot register for a 3-hour course that meets on Tuesdays and Thursdays from 11:0012:30, which can be a significant challenge for students who are juggling multiple commitments outside of school, including work schedules and family. Further, and perhaps most importantly, this 3-hour corequisite, while not eligible for college credit, will count toward full-time enrollment, meaning students will not have an additional time commitment outside their required coursework that counts toward enrollment. Furthermore, the 3-hour corequisite will make students eligible for both financial aid and NCAA and UIL activities. Instructors for both the reading/writing and math corequisites are developing this format over the Summer of 2018 and will be working closely with the faculty in those departments that teach the credit-bearing course so that the corequisite will be closely aligned and able to best support students. TSI staff will continue to monitor and track students with lower TSIA scores enrolled in the 3-hour corequisite to ensure they are successful in their credit-bearing courses.

\section{Suggestions From Practice}

The program that has completed the most research on corequisite models, the Accelerated Learning Program (ALP) housed at the Community College of Baltimore County (2018), has developed a model in which the same instructor teaches both the credit portion of the corequisite and the developmental section of the corequisite. While this has been a popular model to implement, there is not yet consensus regarding this practice. Outside of the potential negative outcomes for the non-developmental students in the credit course, there is a conceivable benefit to employing the model of using separate instructors for each. For those institutions that wish to use the same-instructor model but must first credential their developmental reading and writing instructors to teach college-level courses in order to do so, they can continue to enroll developmental students in credit-bearing courses taught by existing faculty in those departments while allowing their developmental instructors to teach the developmental corequisites.

Finally, though a result of the overall small population of students in need of developmental education at the University of Texas at Austin, the authors recognize that the number of students participating in the presented corequisite models is small compared to other institutions. Furthermore, while the student outcome data presented here are from only the previous 2 academic years in which the model has stabilized in terms of pedagogy, 
scheduling, and placement, data from the combined four years of corequisite implementation suggest that the university's practices for corequisites are promising in terms of student success in credit-bearing courses early on in their college careers.

\section{References}

American Psychological Association. (2018). Ethnic and racial minorities and socioeconomic status. Retrieved from http://www.apa.org/pi/ses/ resources/publications/minorities.aspx

Berliner, D. (2006). Our impoverished view of educational research. Teachers College Record, 108(6), 949995.

Berman, J., McCormack, M., Koehler, K., Connolly, F., Clemons-Erby, D., Davis, M., \& Curriero, F. (2018). School environmental conditions and links to academic performance and absenteeism in urban, mid-Atlantic public schools. International Journal of Hygiene and Environmental Health, 221(5), 800-808. doi:10.1016/j. ijheh.2018.04.015

Burger, E. B., \& Starbird, M. (2009). The heart of mathematics: An invitation to effective thinking $\left(5^{\text {th }}\right.$ ed.). Austin, TX: Wiley and Sons Publishing.

The Community College of Baltimore County. (2018). Accelerated Learning Program. Retrieved from http://alp-deved.org/

Dee, J. (1659). A true \& faithful relation of what passed for many yeers between Dr. John Dee...London, England: Maxwell.

El-Hindi, A. E. (2003). Connecting reading and writing: College learners' metacognitive awareness. In N. Stahl \& H. Boylan (Eds.), Teaching developmental reading (pp. 350-362). Boston, MA: Bedford/St. Martin Press.

Elbow, P. (1997). High stakes and low stakes in assigning and responding to writing. New Directions for Teaching and Learning, no. 69 (pp. 5-13).

Goudas, A. (2017, March). The corequisite reform movement: An education bait and switch. Community College Data. Retrieved from http://communitycollegedata.com/articles/thecorequisite-reform-movement/

Harlow, H. F. (1958). The nature of love. American Psychologist, 13, 673-685. Retrieved from https://psychclassics.yorku.ca/Harlow/love.htm

Hjortshoj, K. (2009). Transition to college writing. Boston, MA: Bedford/St. Martins.

Holschuh, J. P., \& Paulson, E. J. (2013). The terrain of college developmental reading. College Reading \& Learning Association. Retrieved from https://www.crla.net/images/whitepaper/ TheTerrainofCollege91913.pdf

Hunter, E. (1957, July). On the sidewalk bleeding. Manhunt. Retrieved from http://theliterarylink.com/ sidewalk.html
Jensen, E. (2013, May). How poverty affects classroom engagement. Educational Leadership, 70(8), 40-43. Retrieved from http://www.ascd.org/ publications/educational-leadership/may13/ vol70/num08/How-Poverty-Affects-ClassroomEngagement.aspx

Kepler, J. (1617). Ioannis Keppleri Harmonices mundi libri $V$. Linz: loannes Plancus.

Pacioli, L. (1494). Su[m]ma de arithmetica geometria proportioni [et] proportionalita. Venice, Italy: Paganinis.

Pacioli, L. (1509). De divina proportione. Venice, Italy: Paganinis.

Parker, J. (2005). R. L. Moore: Mathematician and teacher. Washington, D.C.: The Mathematical Association of America.

Quinn, K. B. (1995). Teaching reading and writing as modes of learning in college: A view of the future. Literacy Research and Instruction, 34(4), 295-314.

Ramos-Sánchez, L., \& Nichols, L. (2007). Self-efficacy of first-generation and non-first-generation college students: The relationship with academic performance and college adjustment. Journal of College Counseling, 10(1), 6-18.

Rescher, N. (1998). Science and Technology Studies Series. A philosophical overview. New York, NY: Routledge.

Solomon, D., \& Weller, C. (2018, February 21). Systematic inequality: How America's structural racism helped create the black white wealth gap [web blog post]. Retrieved from https://www.americanprogress.org/issues/ race/reports/2018/02/21/447051/systematicinequality/

Tex. H. B. 2223, $85^{\text {th }}$ Leg. (2017).

Tucker, A. (2018, March). A $21^{\text {st }}$-century reimagining of Norman Rockwell's “Four Freedoms." Smithsonian. Retrieved from https://www.smithsonianmag. com/arts-culture/21st-century-reimaginingnorman-rockwells-four-freedoms-180968086/ 